never been translated or performed in English.

Who will read this book? Who should read it? Scientists, playwrights, directors, humanists. It is unquestionably a scholarly work, comprehensive, utilizing many sources, thoroughly referenced and heavily annotated. Parts of it read as if they are composed of essays that could stand alone, making it occasionally repetitive. On the other hand, it is a surprisingly breezy and entertaining read.

One could hope that this book might insti- gate university courses, perhaps taught jointly by professors in science and theatre departments. Such a course could be equally engaging to students in physics, chemistry, biology, mathematics, literature, drama, history whoever heard of such a thing? As a working scientist I am left with only one question: why aren't there any science comedies?

Stuart Firesteinis in the Department of Biological Sciences, Columbia University, New York, New York 10027, USA.

\title{
Sermons and straw men
}

\section{The God Delusion \\ by Richard Dawkins \\ Bantam/Houghton Mifflin: 2006. 416 pp \\ $£ 20 / \$ 27$}

\section{Lawrence M. Krauss}

Early in The God Delusion, Richard Dawkins quotes Thomas Jefferson's statement: "I am satisfied, and sufficiently occupied with the things which are, without tormenting or troubling myself about those which may indeed be, but of which I have no evidence."

This eminently scientific sentiment was echoed two centuries later by the physicist Steven Weinberg, who, like Dawkins, is an outspoken critic of religion, but who has nevertheless suggested that most scientists simply don't spend enough time even thinking about God or religion to merit the label atheist.

But Richard Dawkins is a man on a mission. This new book is the culmination of his recent campaign, which has included a two-part television documentary, aired in Britain, to help humanity rid itself of what he surely views as one of its most vile creations: God.

Before I proceed further, I should, in the interests of full disclosure, confess that I have written exactly one fan letter that I can remember to an author. That letter was written to Richard Dawkins after the publication of a small book, River Out of Eden (Weidenfeld \& Nicolson, 1995), which I felt was perhaps the most concise and cogent science writing, as well as the clearest discussion of the nature of evolution, I had yet read.

I wish that Dawkins, who has a gift for making science - in particular, evolutionary biology - both exciting and understandable to a broad audience, had continued to play to his strengths, which are desperately needed now more than ever as we confront growing attacks on the teaching of evolution, not just in the United States but in the UK and Europe.

Dawkins the preacher is less seductive. And make no mistake: this book is, for the most part, a well-referenced sermon. I just have no idea who the intended parishioners might be. In his preface, Dawkins claims he hopes to reach religious people who might have misgivings, either about the teachings of their faith or about the negative impact of religion in the modern world. For these people, Dawkins wants to demonstrate that atheism is "something to stand tall and be proud of ${ }^{\prime}$.

I found this slightly puzzling. I don't believe in Santa Claus, but I am not particularly proud of it. Indeed, I am rarely, if ever, proud of not believing in things. More generally, I think the strategy of focusing on telling people what not to believe is less compelling than positively demonstrating how the wonders of nature can suggest a world without God that is nevertheless both complete and wonderful - an argument that Dawkins reserves for the final few pages of the book. And while there is a lot to complain about in the ubiquitous facile piety so prevalent today, complaining can nevertheless start to get tiresome. Carl Sagan's The Demon-Haunted World (Headline, 1996) likewise too often mirrored Sagan's frustration at all those who over many years have continued to confront him with their superstitions, but it also conveyed his sense of awe and wonder about nature in a way that Dawkins elsewhere has so craftily displayed.

A less sympathetic reader than the author's wife (who apparently read the entire manuscript aloud to Dawkins for him to review) might have provided a more useful foil. Several indulgences detract from the flow, but more importantly,
I was struck at how Dawkins' presentation, particularly in the early chapters where he builds his case against God, might offend those who, like myself, are quite sympathetic to his central thesis. I suspect that few thinking people of faith are unaware of the remarkable evil that has been done in the name of God, or the possibility that, although most cultures worship some god, this could be a mere reflection of the workings of the human brain rather than definitive evidence for God's reality. Yet Dawkins seems to suggest early on that even agnostics might never confront these issues and that he needs to "raise their consciousness", as he puts it. At the very least I find it doubtful that constantly questioning the intelligence of 'true believers' will be helpful in inducing any such reader to accept Dawkins' strongly argued thesis that both God and religion are nonsensical and harmful.

While I usually tend to begin a review with praise and end with reservations, the reverse order here reflects the progression of my own reading of The God Delusion. There are gems in the book, as one might expect from a writer as powerful as Dawkins, but most of them are in the second half of the volume. He ends the first half with what I found to be a less than compelling probabilistic argument against God. (Incidentally,

I couldn't help wondering, somewhat facetiously, when Dawkins used an anthropic argument from cosmology to argue against God, that, although indeed only very rare universes may harbour life, if an infinite number of universes exist, could not at least one then harbour what might pass for a divine being?)

But after this Dawkins proceeds to brilliantly review the roots of modern morality and the changing moral 'zeitgeist', as he calls it. With authority and wit, he marvellously dissects the absurdity, hypocrisy and selectivity that is inherent in so much of modern biblical morality. Perhaps there can be no higher praise than to say that I am certain I will remember 
and borrow many examples from this book in my own future discussions.

Finally, his treatment of religion and childhood is, I believe, precisely accurate. We do our children a great disservice (which Dawkins goes so far as to call abuse) by forcing religion upon them at an age where they are far too young to digest the deep and subtle issues associated with the possibility of divine purpose. In doing so, we encourage them to rely on potentially destructive emotions rather than to use their brains. And pondering how to build a world of adults that might result from the latter rather than the former is surely what motivates Dawkins here, even if his approach might also provoke some religious fundamentalists to harden their unfortunate belief that knowledge and reason are dangerous things, to be avoided at all costs.

Lawrence M. Krauss is Ambrose Swasey Professor, and director of the Center for Education and Research in Cosmology and Astrophysics, at Case Western Reserve University, 10900 Euclid Avenue, Cleveland, Ohio 44106-7079, USA. His most recent book is Hiding in the Mirror.

\section{The hero of Gombe}

\section{Jane Goodall: The Woman Who Redefined Man \\ by Dale Peterson \\ Houghton Mifflin: 2006.672 pp. \$35}

\section{W. C. McGrew}

In this age of hyperbolic subtitles - such as Frans de Waal's Our Inner Ape: A Leading Primatologist Explains Why We Are Who We Are (Riverhead, 2005), or Richard Dawkins: How a Scientist Changed the Way We Think (Oxford University Press, 2006) - comes another with a major claim. Dale Peterson has produced the long-awaited, definitive biography of (arguably) the world's leading figure in primatology.

$\mathrm{He}$ is surely well qualified to do so, not only as an award-winning author, but also as the editor of two previously published volumes of Goodall's letters, as well as the co-author with her of an influential book that crossed disciplinary lines (Visions of Caliban, Houghton Mifflin, 1993). But might he be too close to his subject to be able to give us an objective account? Might his ambitious subtitle be exaggerated? Happily, the answer to both questions is no.

Goodall is first and foremost associated with wild chimpanzees - more particularly, with one small population of these African apes living on the eastern shores of Lake Tanganyika, in western Tanzania. Her study of the chimpanzees of Gombe, begun in 1960, continues to this day, and has spawned many books, films and articles, both scientific and popular. Indeed, our view of that species, which (along with the bonobo) is humanity's nearest living relation, was shaped, at least in the West, by Goodall's early researches, as reported widely by the National Geographical Society. Few of us have not seen the evocative images of the slim, pony-tailed young woman and her hairy subjects in the Edenic surroundings of Gombe.

But what of the subtitle's claim, that she has redefined our species, Homo sapiens? This originates in the response of Louis Leakey, the flamboyant archaeologist and mentor of Goodall, to her unexpected finding that the apes not only used tools but also made them, as part of their extractive foraging. He stated, with characteristic panache, that now we must redefine 'tool', redefine 'man', or accept chimpanzees as humans. This blurring of longestablished boundaries was further advanced by Goodall's observations of chimpanzees doing other human-like things, such as hunting, cannibalism, warfare, adoption and ritual-like displays.

The book is comprehensive, following Goodall from her childhood interest in animals through her somewhat chequered young adulthood as debutante and waitress. The breakthrough came with a self-financed trip to Kenya, where she met Leakey, who set her on the route to primatology, although she had no prior training nor higher education. Her . aptitude showed quickly as she met chimpanzees on her first day in the field and discovered tool use and meat eating within the first few months. These successes led to her acceptance at the University of Cambridge, UK, to do a doctorate in ethology, despite nothaving a first degree. From that point onwards, she never looked back.

Peterson writes vividly. Descriptions of early days at Gombe, based on excerpts from Goodall's field notes and letters home, come alive. Days in the forest or on the savanna capture the downs (ill health, frustrations with sparse resources) as well as the ups (discovery of totally new phenomena, fast friendships) of field work. Key incidents, such as the Gombe kidnapping, in which four students were held for ransom by Congolese rebels, are revealing; for instance, for weeks in captivity, they had but one English-language book, Niko Tinbergen's The Herring Gull's World (Collins, 1953).

Heroes and villains abound. A series of older male mentors, such as Robert Hinde at Cambridge and David Hamburg at Stanford University, California, were instrumental in guiding the neophyte Goodall. Others were less helpful, such as the zoologist Solly Zuckerman, who, in chairing the symposium at which Goodall first presented her results, dismissed them as fantasy. Lesser egos would have been crushed. The National Geographic Society was both saviour and censor, providing vital funding in the early days, but repeatedly restricting her efforts to present her findings. Easily the most influential figure, however, was Leakey, who although crucial to Goodall's emergence, also complicated her life on personal and professional fronts. Having offered her the Gombe project, he then offered it to another attractive young woman, and kept Goodall waiting for months, until the other turned it down.

Peterson gives the reader useful endnotes but a limited list of references: this is not the place to learn about primatology. The photographs are disappointing, all being in black and white, and mostly snapshots.

The book could have been called 'The Many Lives of Jane Goodall', given her several career transitions: from chimpanzee expert, to distinguished scientist, to committed conservationist, to animal-welfare activist, to global campaigner for the environment, to eminent 'world citizen' in the causes of youth and peace. She would be famous for any of these incarnations, although Peterson is a bit over the top in terming her the most visible scientist of the twentieth century (cf. A. Einstein) and the best-known female scientist in history (cf. M. Curie). Regardless of this, Peterson's volume is the one for which Goodall's devotees have been waiting, and it will deservedly enjoy much success.

W. C. McGrew is at the Leverhulme Centre for Human Evolutionary Studies, Department of Biological Anthropology, University of Cambridge, Cambridge CB2 3DZ, UK. 